\section{Tracks in time}

\author{
Douglas Palmer
}

The Palaeobiology of Trace Fossils. Edited by Stephen K. Donovan. Wiley: 1994. Pp. 308. £39.95, \$63.95.

THE study of trace fossils has come a long way from the odd photograph of a chubby baby sitting in one of the large sauropod dinosaur footprints at the Paluxy River site in Texas (as reproduced in A. S. Romer's Man and the Vertebrates). Today, television has led us to expect a more dynamic approach. I remember McNeil Alexander strutting his stuff complete with stetson in a Second World War amphibious landing vehicle, speeding across the sands of Morecambe Bay, England, with pony and rider alongside changing gait and stride length with increasing speed. The purpose of all this was to illustrate a method of calculating the speed of dinosaur locomotion from the spacing of their footprints as recorded by trace fossils in sedimentary rocks.

But I exaggerate slightly. As Adrian Hunt and his co-authors of chapter 9. "The palaeobiology of vertebrate coprolites", remind us, trace fossils have a pedigree stretching back, as so often in the 'natural sciences', to nineteenth-century clergymen such as Dean Buckland. As early as 1823, he used the evidence of a very particular type of trace fossil. namely coprolites (faeces), to interpret a Pleistocene cave as a hyena den. Consequently, he was able to show a direct

New in paperback
Evolution and Extinction edited by W. G.
Chaloner and A. Hallam. Cambridge
University Press, $£ 22.95, \$ 37.95$. Well-
presented proceedings of a joint
symposium of the Royal Society of
London and the Linnean Society held in
1989. Contributors include J. Maynard
Smith, A. K. Knoll, M. J. Benton, D. M.
Raup and J. M. Diamond.
Visions of Caliban: On Chimpanzees and
People by Dale Peterson and Jane
Goodall. Houghton Mifflin, \$12.95.
"Beautifully written, easily read and
ethically challenging--it might just
become primatology's Silent Spring"
(Alison Jolly, Nature 362,$678 ; 1993$ ).
Fuzzy Thinking: The New Science of
Fuzzy Logic by Bart Kosko. A popular--
and slightly breathless--account by a
pioneer in the field. Hyperion, \$12.95.
Germs, Seeds and Animals: Studies in
Ecological History by Alfred W. Crosby.
M. E. Sharpe, £14. A collection of
previously published essays in which a
noted historian discusses the biological
and ecological consequences of
European expansion since 1492 .
Fascinating and entertaining reading.

comparison between modern hyena scat and the fossil coprolites and bone damage with that produced by a circus hyena.

Unfortunately, the limitations of Buckland's neontological methodology are even more severe for the study of trace fossils than they are for palaeontology in general. The very nature of trace fossils and their preservation history is such that rarely do we know 'who dunnit'. So the question of taxonomy is somewhat problematic to say the least, but is confronted by Ron Pickerill in the opening chapter of this stimulating new book.

Stephen Donovan has brought together a wide range of essays with a focus on different aspects of the evolution and palaeobiology of trace fossils, from the "Functional morphology of boring and burrowing invertebrates" by Enrico Savazzi, elegantly illustrated and with a warning note about the limitations of this kind of analysis, to the now familiar territory of the 'dino' trackers. Martin Lockley and colleagues discuss vertebrate tracks in the context of the ichnofacies concept. This builds on a recent spate of books (such as D. D. Gillette and M. J. Lockley's Dinosaur Tracks and Traces (Cambridge University Press, 1989) and Tony Thulborn's Dinosaur Tracks (Chapman and Hall, 1990)) reflecting something of a renaissance in the study of dinosaur footprints, which are probably more common than dinosaur bones. So much so that it is possible to extend Dolf Seilacher's concept of recurring assemblages of similar trace fossils associated with particular sediment types (facies, and hence ichnofacies) to recurring collections of dinosaur footprints, although the latter are inevitably more restricted in their temporal range.

Donovan himself contributes a timely essay on insects and other arthropods as trace-makers in non-marine environments. This area is attracting a lot of attention, and even since the publication of this book there is new evidence from the British Lake District (E. W. Johnson et al., Geological Magazine 131, 395; 1994) that continental environments were probably colonized much earlier than was previously thought. And the critical evidence is recorded by trace fossils made in shallow freshwater volcanogenic sediments from the Borrowdale Volcanic Group by myriapod-like arthropods as long ago as Ordovician times.

The contribution that the study of trace fossils has already made and will undoubtedly continue to make far outweighs semantic problems. This book is a useful and stimulating collection of essays that should be read by anyone interested in new ways of understanding life of the deep past.

Douglas Palmer is at 31 Mawson Road, Cambridge CB1 2DZ, UK.

\section{Cosmic integers}

\section{John Polkinghorne}

Is There A Universe? By Stanley L. Jaki. Liverpool University Press, UK: 1994. Pp. 137. £16.50 (hbk); £8.95 (pbk).

COSMOLOGY is very much part of the current scientific agenda and its popularizations find their place in the small change of educated conversation. It is surprising to be reminded, as we are by Stanley Jaki, of how late a development in thought the subject is and how many people previously resisted talk of the Universe, understood as the totality of things. Jaki sees Einstein's relativistic cosmology of 1917 as a key development representing the first respectable way of speaking of a cosmos and also avoiding the paradoxes that Newtonian gravitation brought to the concept. Yet he regards science as of comparatively little use in addressing the question of his title: "Such an entity [the Universe], if it is to be spotted, calls for philosophical eyes, eyes usually very weak in scientists". Questions of realism or idealism, being or becoming, the existence of an actual realizable infinity, are all held to lie behind the question.

Jaki is very learned and there is much interesting material in this book, which is based on lectures given at the University of Liverpool. Jaki is also very polemical, and scornful of those whose ideas do not precisely match his own concepts, derived from the philosophy and theology of Thomas Aquinas. He is a chronicler of intellectual endeavour, but he lacks a historian's sympathy for the perspectives of the past. All is illuminated by hindsight and all must pass through the sieve of Thomist orthodoxy. Many celebrated figures incur Jaki's wrath: Plato, Kant and, archvillain of them all and no doubt consigned to the lowest circle of the Jakian hell, Niels Bohr. When we come to Jaki's own answers to his question, they prove to be rather odd, and to me unconvincing. Countability is the key - "a property absolutely indispensable for the purposes of science" - and the integers enable Jaki to give a positive answer to his own question, It seems that for him. existence is enumeration.

John Polkinghorne is president of Queens College, Cambridge CB3 9ET, UK.

- The Fermi Solution: Reflections on the Meaning of Physics by Hans Christian von Baeyer has just been issued by Penguin in the UK ( $£ 6.99$ (pbk); published last year by Random House in the USA). The essays first appeared in The Sciences and Discover and are by the author of the highly praised Taming the Atom (see Nature 361, 215; 1993). 